\title{
Tourism Planning and Management of Canada's Northern Territories
}

Elena Egorovna Totonova*

North-Eastern Federal University, Sakha Republic, Russia; elena.totonova@mail.ru

\begin{abstract}
Tourism development in the North is one of the tools for the new management of the northern territories of Canada which is impossible without its regulation both by the state and local authorities. Tourism development in the North depends on the degree of the territory development which influences the management of the infrastructure, as well as on the government regulation. Spatial differences of Canada's northern territories in the latitudinal and meridional directions determine the specificfeatures of the land management and the development of tourism. It was proved that the development of the tourist market in the northern territories leads to a change in the functioning of this sector, and this new modelcan combine effective market mechanisms and traditional ways of natural resources use being part ofthe specific entrepreneurial resources of the North (cultural heritage, traditional knowledge, indigenous communities, etc).
\end{abstract}

Keywords: Co-operatives, Indigenous Population, Local Government, Spatial Development, The North, Tourism

\section{Introduction}

In recent years tourism has been playing an increasingly important role all over the world due to the growing impact of this sector on the global economy. This also results in the growing popularity of adventure, ecological and exotic tourism in the global tourism industry, which facilitated the development of tourism in the countries of the Arctic Basin: The US, Canada, Iceland, the Nordic countries and Russia.

Tourism as a branch of economic activity is based on the targeted and wise use of resources sufficient for meeting the potential needs of tourists. The objective characteristic of the tourism resources of the region lies in the fact that they can be used not only by tourists but by the local population and other categories of customers. Tourism resources facilitate the tourism business and are considered as one of the factors in the development of tourism, the basis for planning the tourist product offer.

In this paper Canada's North is defined as a territorial and economic entity, functioning in extreme natural, medical and biological conditions. In terms of the administrative-territorial aspect, these are Yukon, Northwest Territories and Nunavut that are located in the coastal area of the Arctic Ocean and have not only similar climatic conditions, economic structure, but the same social problems of indigenous peoples. At the same time, the Canadian North, being substantially different from the southern regions of Canada both regarding the structure of its economy and economic conditions, is composed ofvarious components. In its turn, the heterogeneity of the economic space of the North Canada has a significant impact on the structure and efficiency of the economy, which impel the system of public authorities and local governments to search for mechanisms to regulate the economywhich could be adapted to the harsh conditions of life and changes in the modern economy, still preserving traditional lifestyles of indigenous population.

Development of tourism is one of the ways to increase competitiveness and diversification of the economy of the northern areas. The development of the tourism industry in the north of Canada is followed not only by the increasing flow of tourists and hence creation of new jobs, bigger investments, the growth of household incomes and local government budgets, but alsoit helps to solvethe social problems of the indigenous population.

A distinctive feature of the tourism in the North, including the North Canada, is that it has a considerably

\footnotetext{
* Author for correspondence
} 
less destructive impact on the environment (compared to mining or oil and gas industry), along with a positive influence on the traditional economies of the indigenous peoples and promotion of products created by them on the world market. Tourism development in the North is one of the tools in the Canada's northern territories management, which is impossible without regulation both by the state and local governments. Thus, the relevance of the study stems from the reasons discussed above and the carried out research on the development and management of tourism in Canada's northern territories.

\section{Literature Review}

Since the problems of the relationship between industries and regions turned out to be in the focus of research, i.e., the issue that for decades has been developed both from the perspective of the industrial markets theory and numerous theories of regional development, one must admit that the problem has been explored quite well regarding its theoretical aspect. Only in recent decades there have been published several dozens of general works on the subject, among which those that influenced the author's position are the papers by A. G. Granberg, P. A. Minakir, A. N. Demyanenko, etc.

However, if analyzing not the industry itself, but the tourism industry, and not all regions but the regions of the Arctic and northern Canada, we will see that level of investigation of this problem, at least in Russian economic science, remains fairly low. In this regard, when carrying out an in-depth study of the northern territories, first it is necessary to identify the system of factors that influence the development of tourism and its impact on the specific economy of the North. Therefore, our study of the northern territories was based on a comprehensive approach which included the analysis of natural, social, ethnographic, environmental and economic factors affecting the development of tourism and changing in the course of the North development. When considering works dedicated to the territorial management of the Canada's North economy, special attention should be paid to the works of ${ }^{1,2}$.

\section{Methodology}

Methodologyof this study is based on the fundamental works of Russian and international scientists considering the problems of the formation of industrial markets, including the markets of tourist services, as well as the research on the issues of regional development, including the problems of economic development of the northern regions. Of special note are the works of both Russian and international researchers dedicated to the principles of the regional policy development, also in relation to the northern regions.

The economic data were summarized and studied through the methods of economic analysis, economicstatistical methods, methods of survey, interview, comparative economic and statistical analysis, geographical demarcation, zoning, the study of international practices and expert assessments.

The study identifies the types of organization and regulation of tourism industry in the northern territories of Canada, as well as it assesses the impact of economic development institutions onthe promotion of tourism industry when developing the northern territories of Canada; the paperconsiders the possible areas for application of Canadian practices in the Republic of Sakha (Yakutia).

\section{Discussion}

\subsection{Tourism Development in the North}

The North is the largest of the territorial reserves still existing on the globe, with vast resources that have not yet been involved in the economic turnover. Development of the North seems to be part of a wider process of the development of new areas, occurring at all stages of human evolution. The North can be considered as a separate economic category, reflecting a certain group of socio-economic relations, posed by the need to survive in the areas with harsh conditions, to create there production and life support systems in accord with the interests of the local communities, as well as to maintain ecological balance. With this in mind, the North may be defined as a territorial and economic entity, functioning in extreme natural and economic, medical and biological conditions.

In this paper, Canada's northern territories (Yukon, Northwest Territories, Nunavut) are regarded as a separate economic category. The undertaken analysis considers geographical factors that complicate economic activities in the North (long distances, climatic conditions), institutional factors, socio-economic relations, the interests of indigenous peoples.

It is impossible to imagine modern tourism and creation of tourism products functioning in isolation, 
developing outside national economy. In real economic life they are based on intersectoral industrial cooperation, linking tourism and industries associated with it: Transportation, agriculture, construction, that on the one hand, provide the tourism with necessary resources and technical conditions for the production, i.e., form the material and technical base for tourism, and the other hand, they bring the created tourism products to the customer.

Tourism, as one of the service industries, has certain specific characteristics associated with the nature of the services provided, the product structure, the form of sale and others. In contrast to traditional commodity markets, the specific feature of tourism market is that it does not imply the movement of goods from seller to buyer. On the contrary, the buyers themselves are moved to the destination to obtain the reserved services. Another feature of the tourism market is the large number of different types of sellers that provide not only core but also additional and related services ${ }^{3}$.

Tourism industry is seen as an economic category thatencompasses a set of interrelated industries of the national economy, a single functional task of which is meeting the diverse and constantly growing needs of people forvarious types of recreation and travelling they take in their spare time along with the rational use of all available tourist resources ${ }^{4}$. Economic activities related to tourism are defined in terms of demand, consumption of goods, services for visitors and tourism expenditures they produce. The increase in production in the tourism industry influences other sectors of the economy. Thus, tourism has a significant impact on the economy through the multiplicative effect on various related industries.

Analysis of the tourism industry confirms, first of all, the territorial nature of tourism and its dependence on specific climatic, cultural, historical and other characteristics of the territory. This leads to the formation of different types of territorial tourism systems that are attractive for the development of this or that type of tourism, directly dependent on natural factors.

The forming tourism market is heterogeneous in terms of space. Over the past two decades, tourism has become the main factor of human presence in many areas of the Arctic. The number of tourist visits to the Arctic territories outside Russia (within the boundaries of the Arctic Circle) is increasing every year, from $1 \mathrm{mln}$ people in the early 1990s to about $1.5 \mathrm{mln}$ today ${ }^{5}$. The advancement of transport technology made the wild areas of the Arctic more attractive for recreation. Basically, the northern types of tourism are offered and demanded in the northern countries, such as Canada, the United States (Alaska), Norway, Finland, Sweden and Russia.

Tourism is defined as northern by the territorial differentiation (approximately to the north of $60^{\circ}$ north latitude) in the land where the dominant factors influencing tourist services are natural (remote northern area with cold climate) and ethnographic conditions (culture, lifestyle of the indigenous population) $)^{6}$. Most common varieties of northern tourism can be grouped into three types of nature management, i.e., according to the specific features of natural resources use when meeting the needs of tourists:

- Tourism and recreation (fishing, hunting, recreation),enables simple and expanded reproduction of physical and mental potential of a human.

- Tourism and sports, meets people's need for extended restoration of physical strength (adventures, extreme sports, natural and ecological tourism).

- Educational tourism (environmental, event, cultural and cruise tourism), aimed at the development of intellectual and spiritual needs of a man.

The category and classification types of the northern tourism may be revised. The changing needs of tourists may lead to the emergence of new special kinds of it, while some extreme types of tourism can gradually move into the category of ordinary and usual ones, from informal (amateur) to formal (organized by state or large private companies) tourism varieties, affecting the spatial differentiation of tourist services and considering tourism in the context of the regional economy ${ }^{7}$.

The tourist market of the northern territories is an important part of the state socio-economic policy, which nowadays is focused on the formation of a new model of this sector which could combine effective market mechanisms and preservation of traditional ways of nature management as part of specific entrepreneurial resources of the North (cultural heritage, traditional knowledge, indigenous community, etc).

\subsection{Spatial Development of the Northern Territories}

At the initial stage the tourism development of the northern territories is affected by natural factors, but later one should take into account such economic factors as the development of information and communication technologies. This changes the spatial development of 
the northern territories due to the technological advance and new policies of the federal government. The remote Arctic regions of Nunavut that have no transport system, but air transport (except for water transport during the short summer navigation), become more "accessible" to the tourists due to the development of new technologies (planes, runways), broadband Internet and satellite communications.

As a result, the areas located in the most unfavorable environmental conditions of the Arctic (Nunavut) turn from peripheral tourist markets into the developing ones that offer expensive but exclusive tourist products. The development of tourist business in the North is also facilitated by the state which supports the participation of indigenous communities in the tourist business. A characteristic development feature is the combination of traditional nature management with extractive industry (the mixed economy). Tourist areas are dynamic entities, changing with the time, and the duration of the zone developmentis determined by the availability of transport, state policy, and development of the territory (Table 1).

Typically, tourist and recreational facilities are situated in the vicinity of unique natural objects such as mountains or the coast of the Arctic Ocean. For example, the main tourist sites and tourist areasof Yukon are located along the Alaska Highway or other motor ways. Comfortable travel over highways is made possible not only by the technical condition of the road, but also by the developed network of motorway service facilities providing the necessary services. The level of road infrastructure service allows improving the quality of tourism services. For example, in Yukon 111,000 tourists (2011) travelled along the Alaska Highway (36\% of the total number of tourists in Yukon ${ }^{8}$ ), which forms a "belt" tourist market and is a so-called "front door" to the Northwest Territories, to the northern tourist areas and the western provinces of the country.

In the Northwest Territories major tourist attractions with unique natural objects are also located along highways. The location of tourist attractions along the highways enables easy access to the destination. The well-developed transport infrastructure allows tourists to travel by car, which significantly reduces the cost of recreation.

Development of the northern territories has its own specific features which result from the climatic conditions, terrain, remoteness from the populated areas. Enterprises of northern tourism industry operate beyond densely populated areas and are considered as a form of the new development of the North. Canada's tourist enterprises inthe northern territories are centered around certain points, depending on the existing environmental conditions and the level of the local economy development. Thus, most tourism businesses are located in the boreal taiga of Yukon and the Northwest Territories, which have well-developed transport infrastructure. Located in the Arctic Archipelago, Nunavut has the smallest number of tourism enterprises. Here, high operating costs caused by the specific conditions represent the main problems for tourism development. According to the current development conditions, Nunavut offers travelers customized, exclusive tourist products that attract a certain segment of the tourist market. Thus, tourism centers influence and change the spatial development of the northern regions.

In the 1970s only Yukon could boast a developed level of tourism. Dawson attracted tourists not only because of its sights of the Gold Rush period, but due to a convenient location along the Alaska Highway. This triggered the emergence of first tourist infrastructure objects, publication of guides, and offer of main types of the northern tourism such as sport hunting and fishing, as well as environmental, sports, cultural tourism. Gradually, the tourism industry in Yukon became the second most important sector of the economy. For example, in 1971 the number of tourists amounted to 180,000 people, by 1980 it was already 340,000. In 1973 Yukon's income from tourism constituted $25 \mathrm{mln}$ dollars which is comparable to the product value of mining for this area in the same year (146 mln dollars). Over the 1968-1980 the number of tourists visiting the Northwest Territories increased six times (from 6,000 to 35,000 people), with $6 \mathrm{mln}$ dollars spent by tourists in 1973. Over 1973-1983 the expenditures of the Northwest Territories government for culture and recreation, i.e., to build the infrastructure of the tourist industry, grew 5 times - from $3.6 \mathrm{mln}$ to 18 mln dollars ${ }^{10}$.

Governments of the northern territories support the development of tourism in the framework of economic expansion of their territories. Regional authorities promote the introduction of new tourist projects, provide businesses with loans at reduced rates, discounts on real estate tax and municipal tax. The developing tourism results in the increasing incomes of the co-operatives producing various products. For example, the first art and crafts co-operatives were created in 1960 in the village 
of Cape Dorset. According to the 1997 data, that year 51 co-operatives were working in the Northwest Territories with income amounting to $144 \mathrm{mln}$ dollars ${ }^{11}$.

Rich natural resources of the North, necessary for the further development of the national economy, required joint action of the state and private businesses, as well as huge investments from both sides. The rapid development of the North was made possible by the huge amount of scientific research, along with the active financing not only from the state but also from private businesses. State policy is a crucial aspect in the development of the northern territories, the result of which is the employment of local people, increasing taxable capacity of the local budget, development of entrepreneurship, tourism and other institutions.

The development of the mining industry, transport and energy infrastructure and the active state policy change the territorial organization of the Canadian North economy. Metal mining centers are being created over the territories of the Canadian North, previously poorly differentiated in terms of economy ${ }^{11}$. Prior to that, without production links between individual enterprises exportingtheir products outside the region, the mining development of the Canadian North was not accompanied by the increase in employment of the native population, or the growth of this group's income. On the contrary, in the considered periodfew tourism centers actively influenced the local economy, not only through the creation of new jobs, but also through improving the quality of the human capital, the development of small and medium businesses and infrastructure.

Growth in tourist activity in Canada's North was accompanied by changes in the territorial organization both in the industry and the whole economy of the northern territories. A characteristic feature of this stage is the formation of the tourist centers in the most developed areas with unique natural landscapes, as well as the creation of a specific tourist area along the Alaska Highway.

Commercial exploitation has changed the lifestyle of indigenous peoples and intensified the struggle for their rights; it has also led to the emergence of strong national non-governmental organizations ("political mobilization"). As a result, the issues of territorial and civil rights of the indigenous population came to the fore in Canada's domestic policy, along with the protection of the natural environment.

\subsection{The North's Co-operatives}

State regulation of the North plays an important role in the evolution of tourism of the northern territories. Tourism development in the northern territories of Canada is an integral part of the state socio-economic policy, which aims at the formation of a new model of this sector (local administration) combined with effective market mechanisms (co-operatives, entrepreneurship), at the same time preservingthe ways of nature management traditional for indigenous peoples (tourism) ${ }^{12}$. As a result, this government policy and the idea of sovereignty have a positive impact on the tourism development in the northern territories.

Agreements on land claims and other rights bring considerable financial resources to indigenous communities; however, the decision on how to use these resources is taken by the community. Aboriginal companies operate in such areas as food production, communal services, provision of services, construction, major and minor works in mining, telecommunications, various means of transport, etc. Co-operatives were created in large settlements, with domination of the indigenous population (90\%), who actively joined thecooperatives $^{13,14}$. In 1958, the federal government launched its first five-year program for the development of the cooperatives in the North. A year later, two co-operatives of folk craftsmen and artists were created in Cape Dorset and Baker Lake municipalities (Nunavut). In the 70s there were 30 co-operatives in the Northwest Territories and Yukon; five years later there were already 41 of them.

The popularity of co-operatives in the North of Canada can be explained by the fact that the indigenous people of the North, the Inuit, were historically united in communities, prototypes of modern co-operatives, due to harsh climatic conditions where a man has to live in a community to survive. The creation of co-operatives in modern conditions provides the local population with employment (although it is seasonal work mostly), income and control over their own resources - the important factors for the economic development of the northern territories.

In many communities the co-operatives are the only private companies working in collaboration and integrated into many areas of the local economy. Basically, Arctic Co-operatives Limited (ACL) work in the retail sector (34) and employ 800 people. In recent years, the North co-operatives have been successfully working 
in publishing, radio, television, telecommunications, snowmobiles maintenance; they organize charter flights for tourists and work in construction. According to the 2008 data, 90 co-operatives have increased their revenues by $13 \%$, i.e., from 1.4 bln dollars in 2007 to 1.6 bln dollars in 2008. In the period of 2007-2008 the assets of cooperatives increased by $7 \%$ (from 2.5 bln dollars to 2.7 bln dollars) (Figure 1; Table 2).

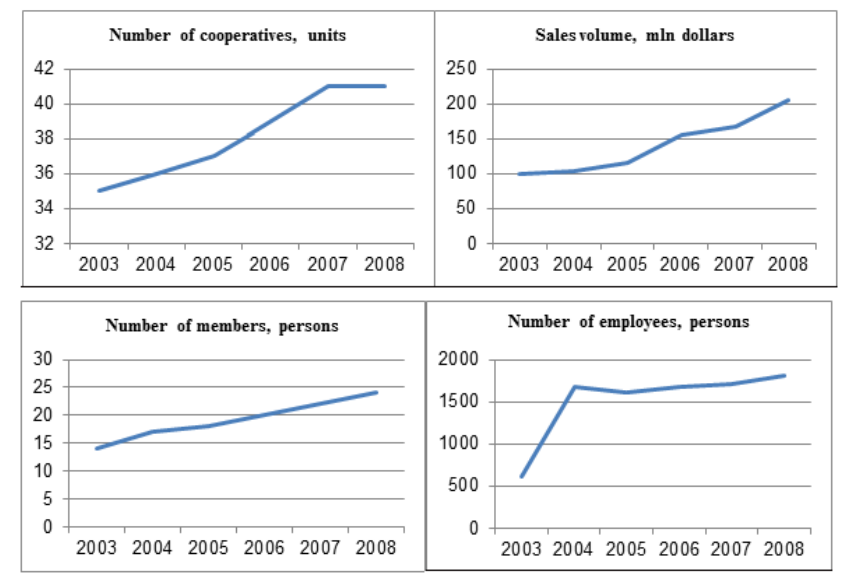

Figure 1. Key indicators of co-operatives in the northern territories of Canada for 2003-2008.

From Les co-operatives au Canada en 2008.Catalogue: A80-901/1-2008F-PD. Secrétariat aux affaires ruraleset aux co-operatives.GovernementduCanada, 2011.

At present moment the co-operatives, acting as economic agents subjected to local self-administration and having a small income, demonstrate a high level of adaptation to changing market conditions and successfully solve social problems of indigenous peoples.

\subsection{Tourism Management in the North}

In Canada, the development of the North is regulated independently: Its stimulation is not focused on the correction of the past mistakes, but on the development of natural resources which until the 60 s was done by private companies under the minor control of the provinces, while in the 70s it was mainly supported by the state. The Ministry of Aboriginal Affairs and Northern Development (established in 1966) ${ }^{15}$ plays an important role in the state regulation of the northern territories as it supports the economic development of the northern territories, municipalities and monitors the implementation of land claims agreements.

Currently, the annual budget of the Ministry amounts to 7.8 bln dollars, about $80 \%$ of this sumpaid directly to the indigenous peoples through transfer payments ${ }^{15}$. Most of it is invested into the development of education, public infrastructure (water supply, sewerage), welfare and housing. Over 2008-2013, the Ministry's budget rose from 7 to 7.8 bln dollars, with average annual growth of $3 \%$, which indicates a growing demand for major programs of the northern territories development ${ }^{16}$.

A new stage of Canada's development is characterized by qualitative changes in the administrative structure of the northern territories implying the introduction of mechanisms for self-government of the indigenous population. A main prerequisite toachieving this objective was the further expansion of the network of economic institutions managed by the indigenous peoples. There are three types of self-government in Canada:

- Reservations or special areas allocated to the indigenous peoples (approved by the Indian Act in 1876, the amendments adopted in 1996). Subjected to the Ministry of Aboriginal Affairs and Northern Development, the reservations are ruled by the community governments (Community Council, Head of Community) that deal with current issues of education, culture, providing of public services and utilities etc.

- Special land claims agreements regulating the relationship between the indigenous peoples and the state - James Bay Agreement (1975) with the Cree and the Inuit of Quebec, the agreement with the Naskapi (1978), the agreement with the Greenwich people in the Yukon Territory (1992), the agreement with the Sahtu Dene and Sahtu Metis people (1994).

- Establishment of national territories (Nunavut). Enforcement of the indigenous peoples' rightsthrough their participation in the management of the territory by means of created municipal governments, in which the indigenous peopleconstitute the majority and can influence the decisions taken by these structures.

The central principle of the Canadian Aboriginal Economic Development Strategy is the principle of cooperation and partnership. Partnerships are developed between federal ministries and agencies as well as between the federal government and indigenous communities. Community self-government bodies are organized on the national and territorial principle; their activities are determined by special regulatory acts taking into account the traditions of the indigenous peoples and the division of powers with the state authorities. Interaction between state, regional and municipal bodies and tourism businesses is the most effective way of tourism management in the Canada's North ${ }^{17}$.

The North tourism development programs correlate with policies (development strategy) of the Canadian 
government which promote socio-economic development of the indigenous peoples by facilitating small businesses. Businesses development in the North requires not only rational use of natural resources, but also expertise in business operations (taxation, preferential investment), which the local population does not have. So, first of all to develop the northern territories, it is necessary to create a variety of programs for training and retraining of the population, i.e., training of local leaders. In 2010 the sum of 1.6 bln dollars was allocated for these purposes (for five years).

Projects for tourism industry development involve construction and upgrading of airports, roads, quays for cruise ships, water purification systems, restoration of cultural and historical objects, creation of museums, tourist information centers, which also contributes to social and economic development of the communities. This increases tax revenues in the local, regional and national budgets from catering and accommodation services, airport taxes, entrance fees for visiting natural reserves etc. Rapid launch and development of tourism in the North was made possible through the government support in the form of transfer payments, as well as existing investment laws. The most popular measures of state regulation are tax breaks, soft loans, grants and support for small and medium-sized businesses. Also, the state facilitates the operation of the regional institutions that contribute to the development of tourism in the North.

\subsection{Possible Applications of the Canadian Experience of Local Self-Governments in Creating the Tourism Management System in Russia}

Transformation of the socio-economic system of Russia required the use of new approaches when devising the institutional environment of the North, as a necessary prerequisite to the northern territories' preparation to the challenges of the new economy. In the times of the Soviet Union, the state was the main institution that regulated all activities in the northern territories. When the reforms began, the state began leaving the North, reducing its presence and contributioninto the development of this region. As a result, the Russian North ${ }^{18}$ suffered mostfrom the reforms undertaken, and many institutions necessary for the development of these areas were destroyed or have not been created yet.

A wide variety of regions and municipalities typical, of these regions, their socio-economic features and cultural identity can be seen as an advantage since, in certain conditions (promoting "local initiatives" within the common legal framework, etc.), it enhances competitiveness. The local self-government is one of the key factors in promoting the sustainable spatial development, since, beingat grass root level of public authority, it directly interacts with the people; thus, on the basis of their interests, local government organizes and is responsible for functioning of most spheres of life of the local community ${ }^{19}$.

One of the major developmental goals of modern municipalities is to improve the efficiency of the local government, which should include the following: Consideration of the management outcomes, rather than the costs incurred; the ability to set right priorities and concentrate resources on solving the key problems forthe area's successful functioning and development; increasing personal responsibility of the managers; consolidating efforts of various departments and organizational units for solving complex problems; improving skills ofprediction, planning and control of the budgetary funds use; development of new forms and methods of management which would be most adequate, on the one hand, in terms of integration and globalization, and on the other - which would take into account the tightening of the international territorial globalization ${ }^{20}$.

Currently, one of the main objectives of Russia's state policy in the field of tourism is creating an efficientsystem of tourism management that would ensure its competitiveness in the global tourism market. This system should be based on the efficient management, coordinating and monitoring the tourism development carried out by different agents. Major parties, representing various management levels are the federal and local governments, representatives of the tourist industry, tourism associations and local communities. Strategic planning of the area facilitates management and regulation of tourism development ${ }^{21}$.

The tourism development strategy allows creating a modern highly effective and competitive tourist complex which can significantly contribute into the economy of the northern regions. When designing the functional strategies for the development of tourism in the northern regions,one should set priorities for organizational, material and financial resources investment: To create a modern marketing strategy to promote tourist products in the domestic and international markets; to develop tourism infrastructure through the creation of conditions 
for attracting state and private investment; to improve the system of regional tourism management; to ensure the priority development of the tourism industry at the regional level by the state authorities; to create the system of local staff training.

It is important to create the competitive sector of tourism and recreational services in the Russian North, first, for purely economic diversification of the economy of these regions which is heavily dependent on the commodity sector; second, for the development of the northern regions that do not have significant industrial capacity; third, for socio-cultural development, as well as fordifferentiation of the economy. The state's mission is to create the efficient and competitive tourism industry that can meet the requirements of Russian and international clients regarding the variety of tourist services, as well as to develop tourism strategies and define the lines of development. At the same time, the state should provide the legal framework and the infrastructure necessary for the development and operation of tourism ${ }^{22}$.

International experience shows that the activities of the local authorities aimed at the development of their municipalities are most effective when they use the methods of strategic planning and management. Moreover, these strategic plans should be drawn up not formally, just because they were requested by superior authorities, but be true outcomes of the social consensus, the development and implementation of which involve representatives of all strata and groups of the local community. This will ensure search for the best ways of interest alignment, which is an important prerequisite for sustainable development of the territory ${ }^{18}$.

Market research based on the comprehensive study of supply and demand plays a significant role in the development of the tourism market. To ensure the tourism development in the region, with certain preconditions for the further industry growth and the participation of the interested operators of the tourist market, it is necessary to develop an integrated marketing strategy for the tourism development of the territory. In this regard, the marketing strategy of tourism development of a territory or the development of a tourist destination is understood as the system of coordinated measures aimed at overall acceleration of the tourism development on a particular territory through the inventory and improvement of certain tourist products and their promotion on the target markets to potential customers ${ }^{21}$.

The most important tasks which influence the tourism development at the regional level are: Selecting methods for assessing the condition of the tourism industry in the region, identifying areas of tourism development that meet the interests of the region, identifying ways to increase the region's attractiveness to tourists, assessing the tourism impact on the socio-economic development of the region.

The management of the tourism industry may be improved through the development of tourism in the regions. Interaction between state, regional and municipal structures with tourist enterprises is the most effective way of tourism management in the North. That is, the relationships of tourist companies with state bodies of tourism management imply: The ability to improve the operation of tourist companies through using scientific methods of activities and management planning, creating an effective system of relationships between tourism enterprises owned by small and medium-sized businesses and government agencies. Only proper management enables to avoid the negative effects of tourism and achieve the most tangible positive results.

As part of tourism development in the Russian North, it is possible to use the Canada's experience concerning the development of various types of co-operatives and local self-governments, which take into account the specific characteristics of employment in the northern territories. The practices of tourism management in the northern territories of Canada represent a valuable experience of administrative efforts of coordination and monitoring of tourism development by different agents. The structure of management includes the federal and territorial governments, representatives of the tourism business, tourism associations and local communities. The main line of the northern tourism development is the revival of national self-government in the indigenous communities, supporting traditional nature management, legal recognition of rights on land use which is the only resource of the northern territories.

\section{Conclusion}

The historically formed heterogeneity of the socioeconomic sphere has a significant impact on the structure and efficiency of economic development of the northern territories. As Canada's experience shows, the economic development of the North becomes sustainable only in case of the simultaneous maintenance of the territory along with the preservation of traditional economies of the indigenous peoples and the environmental management. Tourism is a way to diversify the economy of the North, 
this sector being currently one of the fastest growing ones in the world economy.

The tourist market of the northern territories is an important part of the state socio-economic policy, which in modern context aims at formation of a new model of this sector that combines effective market mechanisms along with preserving traditional methods of nature use as a part of specific entrepreneurial resources of the North (cultural heritage, traditional knowledge, indigenous communities and etc). The development of the northern territories is an example of growing complexity of the tourist industry structure, connected with the economic development of the territory. A characteristic feature of this process is a combination of traditional nature use and extractive industry (the mixed economy).

Creation of local self-governing bodies and their cooperation with business, regulated by the federal and regional governments seems to be the optimal and favorable prerequisite for tourism development in the North. Cooperation between tourism enterprises and state authorities of tourism management enables to improve the work of tourist companies, introducing the scientific methods whenplanning their activities, and to form a system of relations between tourism enterprises and government agencies.

\section{Acknowledgements}

The work is produced as part of RSF No 15-18-20047 "Ontology of the Landscape: Semantics, Semiotics and Geographical Modeling" and RHSF - House of the Human Sciences Fund, France 2015 International scientific and practical conference, "Landscape in the Memory Narrative. Reality.Image.Simulation".The study was financially supported with a grant of the RSF No 15-1820047 "Ontology of the Landscape: Semantics, Semiotics and Geographical Modeling" and RHSF - House of the Human Sciences Fund, France 2015 International scientific and practical conference, "Landscape in the Memory Narrative. Reality.Image.Simulation".

The author expresses her profound gratitude to the colleagues - Associate Professors Lyudmila Sofronova Zamorschikova and Marianna Valentinovna Samsonova for their support and assistance in conducting this study, and to Professor Alexander Nikolayevich Demyanenko for his valuable comments and the discussion of the central ideas of this research.

\section{References}

1. HamelinL-E. Discours du Nord. Collection Recherche 35, GETIC. Quebec: Universite Laval; 2002. [in French]

2. Rea KJ. The political economy of the Canadian North: An interpretation of the course of development in the Northern Territories of Canada to the early 1960's. Toronto: Published in association with the University of Saskatchewan by University of Toronto Press; 1968.

3. Totonova EE. Opytrazvitijaturizmana Severe Kanady: monografija [Experience of tourism development in the North of Canada: Monograph]. Yakutsk: Yakutsk State University Press; 2009. [in Russian].

4. Zhukova MA. Industrijaturizma: menedzhmentorganizacii [Tourism industry: Corporate Governance]. Moscow: Finansyistatistika; 2003. [in Russian].

5. Grenier A A. L'Antarctique 2006-2007: une autre saison de records touristique en perspective. Reseau de Veille en tourisme; 2006 Oct 31. [in French]

6. Totonova EE. Severnyjturizm: ponjatieiklassifikacija [North tourism: Concept and classification]. RISK: Resources, Information, Supply, Competition, 2010; 2:305-9. [in Russian].

7. Shpilko SP. Teorijaiklassifikacijavidovturizma [Theoretical aspects and classification of tourism types]. Tourism and Recreation: Fundamental and Applied Research: Proceedings of the 3rd International Scientific and Practical Conference; Moscow State University, 2008. p. 30-42. [in Russian].

8. Government of Yukon Site. Available from: www.gov.yk.ca/ stats/

9. Minakir PA, Demyanenko AN. Genezisregionalnyhissledovanij [Genesis of Regional Studies]. Pacific Russia - 2030. Khabarovsk: FEB RAS; 2010. [in Russian].

10. Cherkasov A I. ZarubezhnyjopytissledovanijaiosvoenijaSevera [International experience of the north research and development]. Moscow: All-Union Institute of Scientific and Technical Information; 1985. [in Russian].

11. Belhadji B. Profil socio-economique des co-operatives autochtones au Canada. Secretariat aux co-operatives Gouvernement du Canada. - Ottawa; 2001. [in French]

12. Totonova E E. Rolturistskihresursov v razvitiituristskogobiznesasevernyhterritorij [The role of tourist resources in the development of tourist business in the northern territories]. Bulletin of National Tourism Academy, 2011; 3:37-41. [in Russian].

13. Les coopérativesautochtones au Canada Études de cas. Available from: http://publications.gc.ca/collections/Collection/R2-161-2001F.pdf [in French].

14. Aboriginal affairs and northern development of Canada. Available from: www.ainc-inac.gc.ca

15. Affaires autochtonesetdéveloppement du Nord Canada. Available from: http://www.aadnc-aandc.gc.ca/fra [in French].

16. Affaires autochtonesetdéveloppement du Nord Canada Available from: https://www.aadnc-aandc.gc.ca/DAM/ 
DAM-INTER-HQ/STAGING/texte-tex/ai_arp_fin_20122013_bkg-LD_1332853348339_fra.html [in French].

17. Totonova EE. Sovremennyetendenciiformirovanijamestnyhorganovupravlenijaturizmom (naprimereKanady) [Modern trends in development of local authorities of tourism management (through the Example of Canada)]. RISK: Resources, Information, Supply, Competition, 2011; 3:264-7. [in Russian].

18. Sever iArktika v prostranstvennomrazvitiiRossii: nauchno-analiticheskijdoklad [The north and the arctic in the spatial development of Russia: Scientific and analytical report]. Scientific Council for Regional Development of the Russian Academy of Sciences (RAS); Council for Study of Productive Forces under the jurisdiction of the Ministry of Economic Development and the Presidium of RAS; Institute for Economic Problems of the Kola Science Center RAS; Institute for Socio-Economic and Energy Problems of the North Komi Scientific Center, Ural Branch of RAS.
Moscow - Apatity - Syktyvkar - Apatity. Kola Scientific Center, Russian RAS; 2010. [in Russian].

19. Granberg A. Osnovyregionalnojekonomiki [Foundations of regional economy]. Moscow: State University - Higher School of Economics; 2000. [in Russian].

20. Sachuk TV. Territorialnyj marketing [Place marketing]. St. Petersburg: Piter; 2009. [in Russian].

21. Totonova E E. Rolmestnyhorganovsamoupravlenija $\mathrm{v}$ formirovaniisistemyupravlenijaturizmomRespublikiSaha (Jakutija) [The role of local government in tourism management in the Republic of Sakha (Yakutia)]. Management of Economic Systems: Electronic Scientific Journal. 2014; 62. Available from: http://www.uecs.ru [in Russian].

22. Totonova EE, Sleptsov SY. SovremennyeosobennostiprostranstvennogorazvitijaarkticheskihrajonovRespublikiSaha (Jakutija) [Modern features of spatial development of the arctic areas of the Republic of Sakha (Yakutia)]. Economics and Management, 2014; 2:19-23. [in Russian]. 